\title{
Tracking the behavior of rocky coastal cliffs in northwestern Spain
}

\author{
Alejandro Gómez-Pazo ${ }^{1,2}\left[\right.$ D $\cdot$ Augusto Pérez-Alberti ${ }^{2} \cdot$ Alan Trenhaile $^{3}$
}

Received: 16 April 2021 / Accepted: 2 September 2021

(c) The Author(s) 2021

\begin{abstract}
Rocky coastal regions are often inaccessible due to steep slopes and high relief. Remotely sensed data can, therefore, be useful, but they often have low spatial and temporal resolution and, in the case of airborne LiDAR, if not publically available, are costly to obtain. This paper reports on the use of high-resolution images from unmanned aerial vehicles (UAVs) and Structure-from-Motion (SfM) photogrammetric techniques, supplemented by a series of orthophotos and aerial LiDAR, to examine changes in rocky coastal cliffs from 2002 to 2018. The study was conducted over an $800 \mathrm{~m}$-long, orthogneissdominated coastal section in northwestern Galicia, Spain. Cliff changes are due, primarily, to rockfalls, resulting from weathering and wave undercutting, which cause talus deposits to accumulate at the cliff foot. These deposits provide temporary protection to the cliff from wave action, until destabilized and removed by wave erosion and shallow landslides. Cliff recession rates are affected by changing conditions within a cycle and are dependent, in part, on when a survey is conducted. The data suggest that rates of cliff recession are increasing in this region and that the plan shape of the coast, which consists of headlands and bays, is continuing to evolve. Most coastal landslides in this region help to transport and dispose of talus fallen from the cliff. In contrast to landslides that remove intact materials from the cliff face, and are, therefore, primary erosional mechanisms, talus landslides are triggered by wave erosion and probably simultaneously, by storm wave spray and splash, rather than by heavy rainfall.
\end{abstract}

Keywords Rocky coast $\cdot$ Cliffs $\cdot$ Talus $\cdot$ UAV $\cdot$ Galicia

\section{Introduction}

Rock coasts are being impacted increasingly by human activities and infrastructure, which are, in turn, at growing risk from natural hazards promoted by climate change, including the effects of rising sea level and possibly increased

This article is part of a Topical Collection in Environmental Earth Sciences on Earth Surface Processes and Environment in a Changing World: Sustainability, Climate Change and Society, guest edited by Alberto Gomes, Horácio García, Alejandro Gomez, Helder I. Chaminé.

Alejandro Gómez-Pazo

a.gomez@usc.es

1 Department of Geography, University of Santiago de Compostela, Praza da Universidade, 1, 15782 Santiago de Compostela, Spain

2 CRETUS Institute. Universidade de Santiago de Compostela, 15782 Santiago de Compostela, Spain

3 School of the Environment, University of Windsor, Windsor, ON N9B 3P4, Canada storminess (Del Río and Gracia 2009; Trenhaile 2014a; Moore and Davis 2015; Vann Jones et al. 2015; Alessio and Keller 2020). Risk assessment, hazard mitigation, and coastal management in these environments require appropriate data on mass movements and rates of cliff recession, and the formulation of inventories and data-bases that record these events (Nandi and Shakoor 2010; Arbanas et al. 2014; Steger et al. 2017; Esposito et al. 2017; Valenzuela et al. 2018).

This paper is concerned with rocky, coastal cliffs in northwestern Spain. Although not specifically directed towards managerial issues or concerns, the type of data that were collected, and the analysis that was conducted, are fundamental precursors for hazard mitigation and risk assessment on this coast. It has been difficult in the past to acquire the requisite data from rocky coasts that are inaccessible due to steep, unstable slopes and high cliffs. The ability of unmanned aerial vehicles (UAVs) to fly at low altitudes and to traverse difficult terrain provides new opportunities to monitor the behavior of these coasts and, when combined with Structurefrom-Motion ( $\mathrm{SfM}$ ) photogrammetric techniques, to perform 
very-high-precision analyses at fairly low cost (Muñoz Narciso et al. 2017; Warrick et al., 2019; Medjkane et al. 2018; Westoby et al. 2018; Horacio et al. 2019; Buchanan et al. 2020). The purpose of this study was twofold, to assess the utility of UAVs to monitor changes to coastal cliffs, and to use the data, supplemented by air photographs and LiDAR, to provide insights into rates and patterns of slope modification on rock coasts. Consequently, there were two study timeframes, a primary one based on the analysis of highresolution UAV images from 2016 and 2018, and a secondary or extended period from 2002 to 2018 , based on the additional data from air photographs (orthophotos).

\section{Study area}

The study was conducted along an $800 \mathrm{~m}$ section of the coast in northwestern Galicia, northwestern Spain (Fig. 1). Most of the area consists of a shallow bay between two headlands, backed by cliffs that are generally more than $50 \mathrm{~m}$ high and fronted by sandy beaches interspersed with boulders and areas of bare rock (Blanco Chao and Pérez Alberti, 1996). Exposed rock surfaces, which are generally restricted to the upper parts of the cliffs, slope seawards at gradients of $>75^{\circ}$. The presence in many places of talus reduces the gradients in the middle to lower portions of the cliffs to $30-60^{\circ}$ and, where the debris is being transported away from the cliffs, to $5-16^{\circ}$ near the base. Cliff profiles tend to be roughly linear although their shape may be punctuated by steep scarps and associated depressions. Near-vertical wave-eroded scarps or concave ramps are also quite common in the talus at the cliff base, and convex slope elements in the exposed rock near their summits. Mass movements occur as rockfalls from bare rock surfaces and as shallow slides, generally originating in the middle to lower portion of the profiles, in the wave-eroded debris (Fig. 2). The study area is dominated by densely jointed and intensely fractured and weathered biotitic-muscovitic orthogneisses, with a zone in the extreme southwest of schists and paragneisses of medium and high metamorphic grade, and small porphyritic granite dikes. Most analysis in this paper was directed towards six discrete sectors, labeled A-F, where mass movements appeared to be particularly active during the primary 2016-2018 study period (Fig. 1d).

The northwestern coast of Galicia is mesotidal, with an average range of approximately $2 \mathrm{~m}$ and a maximum range of $4 \mathrm{~m}$ (Puertos del Estado 2020). It is the most energetic coast on the Iberian Peninsula, with waves that can exceed $10 \mathrm{~m}$ in height during winter storms (Puertos del Estado 2020). Northwesterly waves predominate, especially during the most energetic events (Fig. 3a). The cliffs in sectors $\mathrm{B}, \mathrm{C}$, and $\mathrm{D}$ are oriented towards these dominant storm waves, but sectors $\mathrm{A}, \mathrm{E}$, and $\mathrm{F}$ are more sheltered, due not only to their orientation but also because of the protective effect of the adjacent headlands. Simulated (SIMAR) data from a station (3030038) approximately $2.19 \mathrm{~km}$ from the study area were used to represent wave conditions over the extended time period (Fig. 1b). To check their validity, the simulated data were correlated against the corresponding values from the two closest wave buoys; each located about $77 \mathrm{~km}$ from the study area (Puertos del Estado, 2020). The non-parametric Spearman's Rank correlation coefficients ( $\rho$ s or rho), 0.914 for Villano-Sisargas and 0.904 for Estaca de Bares, were statistically significant $(p \leq 0.05)$. Significant wave height (Hs) was $>4 \mathrm{~m}$ for $5.54 \%$ of the 2016-2018 study period, the highest waves being especially prominent during winter, when $\mathrm{Hs}>5 \mathrm{~m}$ was exceeded for $3.79 \%$ of the time (Fig. 3a).

A storm event was defined as a period, of at least 6 or $12 \mathrm{~h}$, when the mean hourly wave height exceeded the 95th percentile of the hourly wave height over the entire study period (in this case $\mathrm{H}_{\mathrm{s} .95}>4.11 \mathrm{~m}$ ). The average interval between storm events was 14 days, with shorter intervals in winter and especially in January 2018 (Table 1). The simulated data suggested that the stormiest periods were 2014-2016 and 2017-2018. The highest waves occurred most frequently from 2008 to 2010 , with a general tendency for a higher frequency of high waves $\left(\mathrm{H}_{\mathrm{s}}>5.5 \mathrm{~m}\right)$ before rather than after 2014 (Table 1; Fig. 3b).

Meteorological data for the extended study period were obtained from the Meteogalicia station at Ferrol, about $8.5 \mathrm{~km}$ from the study area (Meteogalicia, 2020). Annual rainfall fluctuated between approximately 850 and $1750 \mathrm{~mm}$, with a tendency for the wettest years to have been before 2007 and after 2012 (Fig. 3c). To assess the effect of persistently wet conditions on mass movement activity, the precipitation data were analyzed to determine the total amount of rain falling over consecutive, discrete, or overlapping, 5- or 10-day periods (5- or 10-day running totals). Rainfall totals were represented by the number of days within 5- or 10-day intervals that exceeded the specified totals. Rainfall frequency and intensity, adjusted for differences in the number of days in each period, were broadly similar, with notable exceptions being 2017-2018 (period VII), which had far fewer 5-day wet events than other periods, and 2014-2016 (period V), which had a particularly high frequency of 10-day periods with more than $50 \mathrm{~mm}$ of rainfall (Table 2). Soil moisture data were also available for 2012-2018 from the Meteogalicia station at $\mathrm{O}$ Val, about $4 \mathrm{~km}$ from the study area (data were not collected before 2012) (Meteogalicia, 2020). The data from this station exhibited strong seasonal behavior, with minimum values in summer and maximum values in winter. Values were closely related to rainfall with soil moisture being highest in the wet winters of 2013-2014 and 2014-2015 (Fig. 3d). 

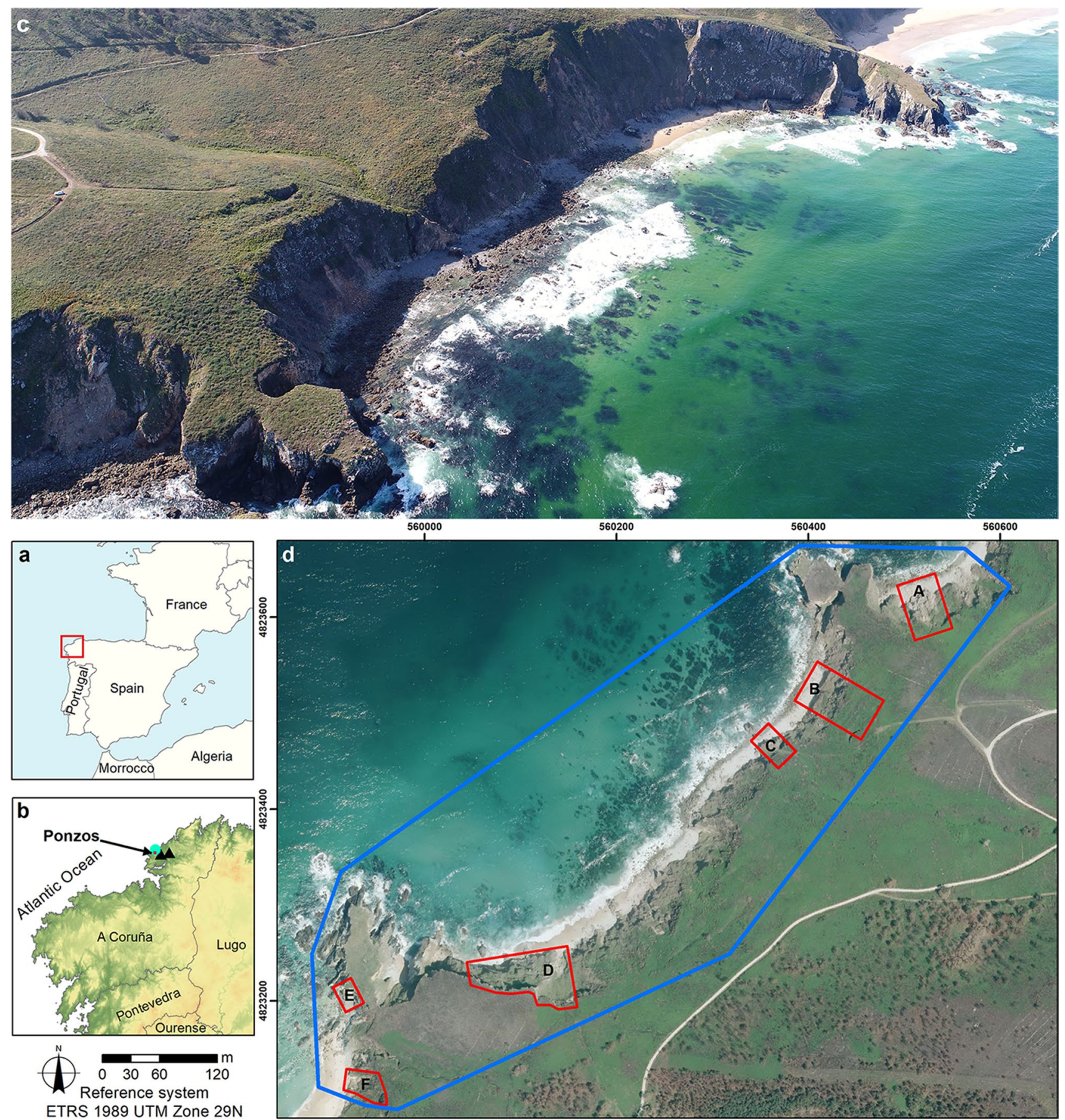

Fig. 1 Location of the study area in (a) western Europe and (b) NW Spain. The blue dot near Ponzos represents SIMAR point 3030038 and the black triangles weather stations (Puertos del Estado, 2020; Meteogalicia, 2020). c an oblique 2018 UAV photo of the study area

\section{Materials and methods}

The primary source of data for this study was two UAV flights in May 2016 and September 2018. The first flight utilized a 20.0 MP ILCE-6000 camera mounted on a with the headland in the lower left being the headland in the top right in (d). d The study area (blue polygon) with the red polygons showing the location of the 6 sectors (PNOA 2017 image, IGN 2020)

Microdrones UAV model md4-200, and the second a FC6310 camera, with the same resolution as on the first flight, on a DJI Phantom 4 Pro UAV (Table 3). Flight planning and data collection were based on the study area, ground control points (GCPs), and the camera. Both UAV 

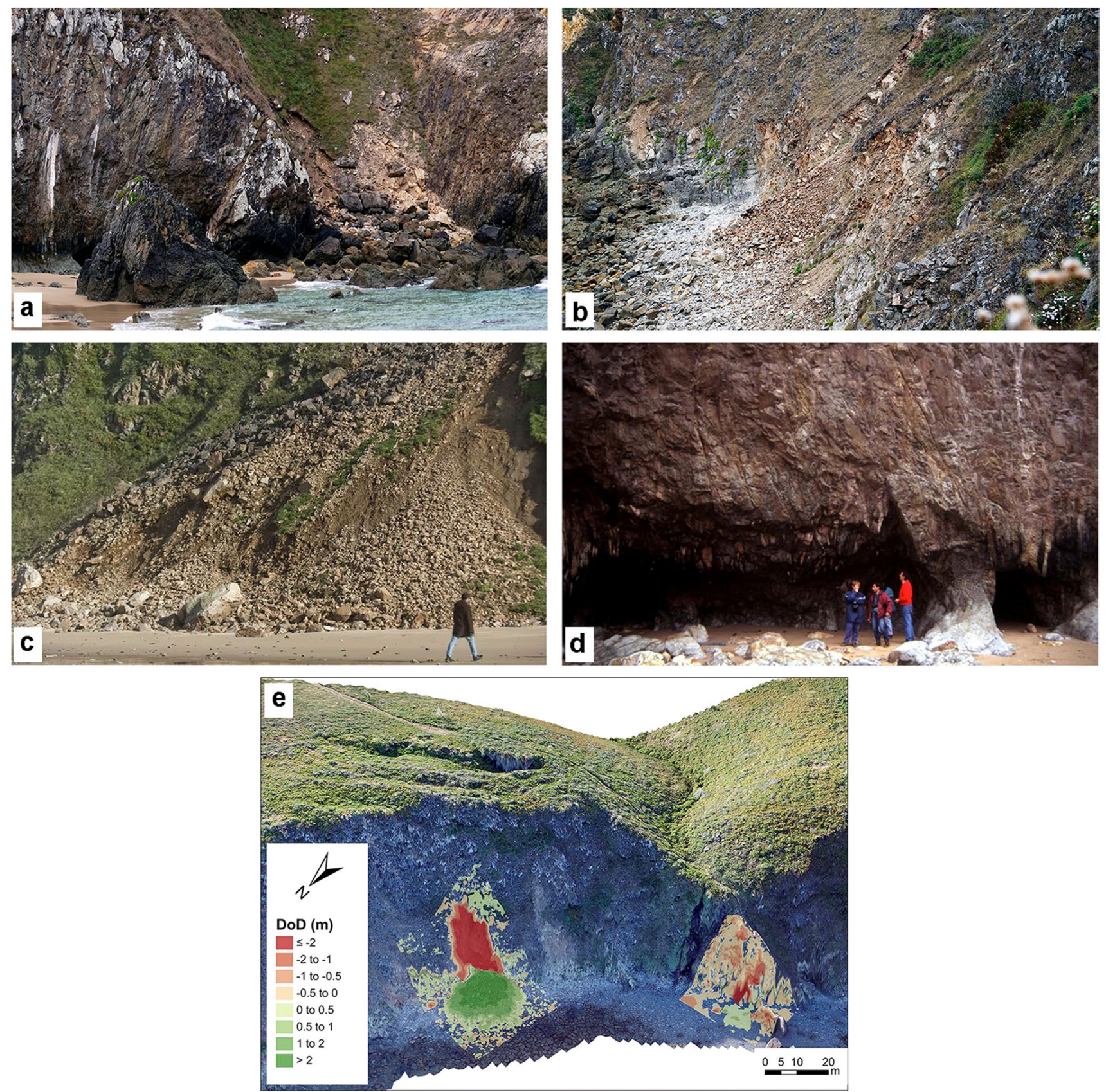

Fig. 2 Shallow slides: a at the headland in the northern portion of the study area; b close to sector D; and c a 2017 slide in section F (Abelairas 2017). d A wave cut notch in sector D. e Three-dimensional model of cliff variations in sectors B (left side) and C (right side). The DSM and orthoimage are from 2018. Changes in the period between the 2016 and 2018 (UAV) surveys are color coded. The slide in sector B is typical of this region with the transfer of material from the central part of the slope to the base, where it becomes accessible to the waves, providing protection to the cliff until it can be removed. The slide in sector $\mathrm{C}$ is at the mouth of a valley and on a much lower part of the cliff. The distribution of pixels affected by surface lowering or rising is more complex, possibly due in part to redistribution of loose material by stream water running down the cliff face. Note the scarp behind cliff top in sector B flights were made at a height of $40 \mathrm{~m}$ above the ground. The frontal and lateral overlap between images was $80 \%$ and each pixel in the study zone had at least 5 images. A Stonex S8 GNSS receiver was used to locate GCPs, which had a vertical accuracy of $10 \mathrm{~mm}$ and a horizontal accuracy of $5 \mathrm{~mm}$.
The UAV data were used to produce two digital surface models (DSMs) with Pix4dMapper (2014) software. The images were processed and filtered to remove erroneous data and damaged files, and processed, using SfM (Structurefrom-Motion) techniques, to transform the information into 

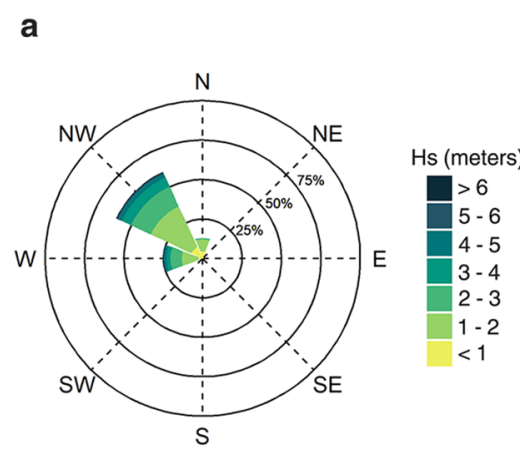

C

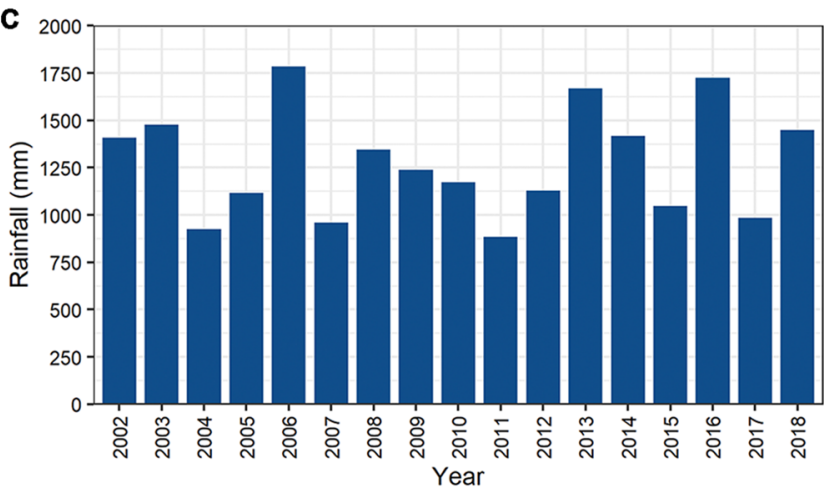

Fig. 3 Significant wave height (Hs) in the study area from 2002 to 2019. a Wave rose; b Mean daily wave height. The black, downwardfacing arrows refer to the aerial surveys with the intervals between the surveys labeled from I to VII. Data from Puertos del Estado 2020

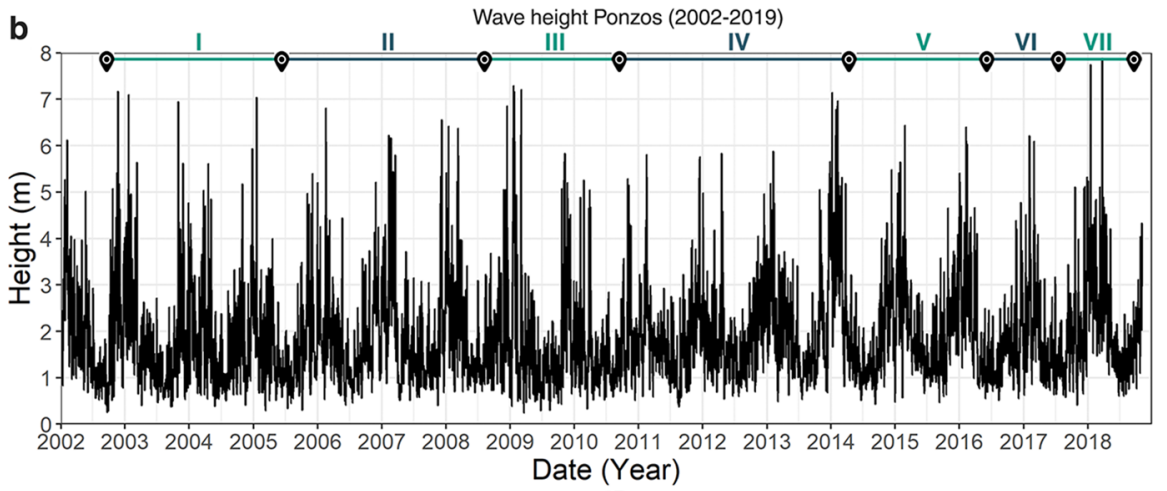

d

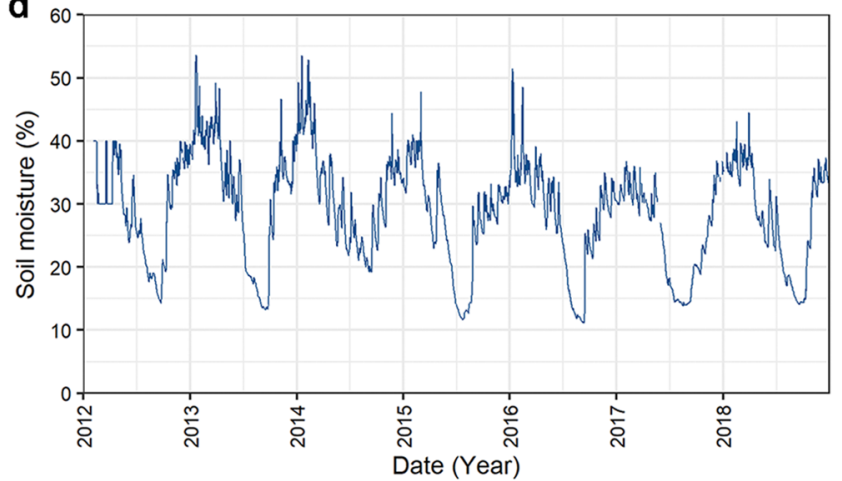

for point SIMAR 3030038 (see location in Fig. 1b). c Annual rainfall for Ferrol (d) Soil moisture content at the O Val station, the closest to the study area (Meteogalicia, 2020)

Table 1 Wave data 2002-2018

\begin{tabular}{|c|c|c|c|c|c|c|c|c|c|}
\hline Period $^{\mathrm{a}}$ & Start & End & No. of days & $\begin{array}{l}\text { No. of storms } \\
(>6 \mathrm{~h})\end{array}$ & $\begin{array}{l}\text { Mean interval } \\
\text { (days) }\end{array}$ & $\begin{array}{l}\text { No. of storms } \\
(>12 \mathrm{~h})\end{array}$ & $\begin{array}{l}\text { Mean interval } \\
\text { (days) }\end{array}$ & $\begin{array}{l}\% \text { days } \\
\text { with } \mathrm{H}> \\
5.5 \mathrm{~m}\end{array}$ & $\begin{array}{l}\% \text { days } \\
\text { with } \mathrm{H}> \\
6.5 \mathrm{~m}\end{array}$ \\
\hline I & 09/15/02 & $05 / 26 / 05$ & 983 & 67 & 14.7 & 45 & 21.8 & 1.12 & 0.41 \\
\hline II & $05 / 26 / 05$ & $07 / 22 / 08$ & 1123 & 65 & 17.3 & 47 & 23.9 & 1.25 & 0.27 \\
\hline III & $07 / 22 / 08$ & $08 / 10 / 10$ & 746 & 46 & 16.2 & 36 & 20.7 & 1.61 & 0.67 \\
\hline IV & 08/10/10 & $09 / 25 / 14$ & 1505 & 109 & 13.8 & 79 & 19.1 & 1.26 & 0.40 \\
\hline V & $09 / 25 / 14$ & $05 / 26 / 16$ & 608 & 60 & 10.1 & 37 & 16.4 & 0.99 & 0.16 \\
\hline VI & $05 / 26 / 16$ & $06 / 18 / 17$ & 387 & 15 & 25.8 & 11 & 35.2 & 0.78 & 0 \\
\hline VII & $06 / 18 / 17$ & 09/11/18 & 449 & 45 & 10.0 & 33 & 13.6 & 0.67 & 0.45 \\
\hline
\end{tabular}

$\mathrm{H}$ refers to mean daily significant wave height $\left(\mathrm{H}_{\mathrm{s}}\right)$ calculated from hourly data

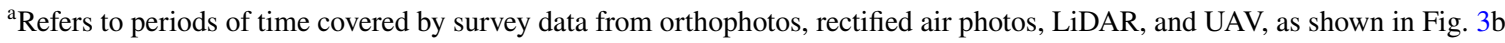

three dimensions in Point Cloud format. To compare cliff morphology in the two flights, a new raster file was created to produce a DEM of Difference (DoD), with positive values corresponding to areas where the surface had been elevated and negative values to areas where the surface had been lowered. A fixed value, equal to the root-mean-square error (RMSE) calculated for the two flights $(0.2 \mathrm{~m})$, was used for the Limit of Detection (LoD) (Wheaton et al. 2010), rather than a variable value related to systematic spatial errors (James et al. 2017). ArcGIS 10.5 and Geomorphic Change Detection (GCD) software (Wheaton et al. 2010) were used to record positive and negative changes in elevation, $>0.2 \mathrm{~m}$, in the DSMs for the two flights. Recorded changes in elevation were used to calculate surficial and, based on the number and total area of the $5 \mathrm{~cm}$ pixels (the resolution of the 2016 images), volumetric differences in the 6 sectors. In a 
Table 2 The number of consecutive 5- or 10-day periods with total rainfall amounts exceeding the listed value

\begin{tabular}{|c|c|c|c|c|c|c|c|c|c|c|}
\hline \multirow[t]{2}{*}{ Period } & \multirow[t]{2}{*}{ Number of days } & \multicolumn{4}{|c|}{ Number of 5-day periods* } & \multicolumn{5}{|c|}{ Number of 10 -day periods* } \\
\hline & & $>150 \mathrm{~mm}$ & $>100 \mathrm{~mm}$ & $>75 \mathrm{~mm}$ & $>50 \mathrm{~mm}$ & $>200 \mathrm{~mm}$ & $>150 \mathrm{~mm}$ & $>100 \mathrm{~mm}$ & $>75 \mathrm{~mm}$ & $>50 \mathrm{~mm}$ \\
\hline I & 983 & 0 & 3 & 33 & 101 & 0 & 11 & 70 & 150 & 267 \\
\hline II & 1123 & 5 & 22 & 54 & 122 & 15 & 27 & 86 & 185 & 313 \\
\hline III & 746 & 0 & 0 & 9 & 48 & 0 & 0 & 29 & 82 & 193 \\
\hline IV & 1505 & 1 & 7 & 32 & 140 & 0 & 14 & 95 & 214 & 422 \\
\hline V & 608 & 1 & 10 & 21 & 82 & 7 & 13 & 57 & 130 & 225 \\
\hline VI & 387 & 0 & 0 & 17 & 35 & 0 & 0 & 13 & 57 & 85 \\
\hline VII & 449 & 0 & 0 & 2 & 20 & 0 & 0 & 8 & 50 & 105 \\
\hline
\end{tabular}

*Number of times when rainfall exceeded the listed value $(>150 \mathrm{~mm}$ or $200 \mathrm{~mm}$ to $>50 \mathrm{~mm})$ over a 5- or 10-day period. Discrete events occurred when the requisite rainfall totals were exceeded over a single 5- or 10-day period. Overlapping events occurred when the running totals continued to exceed the requisite totals over a prolonged period ( $>5$ or 10 days) of heavy rainfall. Periods between surveys (column 1$)$ are defined in Table 1

Table 3 Technical data for UAV, LiDAR, and air photo surveys

\begin{tabular}{|c|c|c|c|c|c|c|c|c|}
\hline \multicolumn{9}{|l|}{ UAV } \\
\hline \multicolumn{2}{|l|}{ Date } & Images & Resolution (cm) & No. GCPs & \multicolumn{2}{|r|}{$\begin{array}{l}\text { RMSE X } \\
(\mathrm{cm})\end{array}$} & $\begin{array}{l}\text { RMSE Y } \\
(\mathrm{cm})\end{array}$ & $\begin{array}{l}\text { RMSE Z } \\
(\mathrm{cm})\end{array}$ \\
\hline $26 / 05 / 2016$ & & 771 & 5 & 6 & & 1.854 & 1.282 & 0.077 \\
\hline $11 / 09 / 2018$ & & 936 & 2.98 & 5 & & 1.122 & 0.831 & 1.609 \\
\hline \multicolumn{9}{|c|}{ LiDAR (source NGI) ${ }^{\mathrm{a}}$} \\
\hline Year & & & \multicolumn{2}{|l|}{ Min. point density } & \multicolumn{2}{|r|}{ RMSE Z } & & $\begin{array}{l}\text { Plani- } \\
\text { metric } \\
\text { accuracy }\end{array}$ \\
\hline 2010 & & & \multicolumn{2}{|l|}{0.5 points $/ \mathrm{m}^{2}$} & \multicolumn{2}{|r|}{$<40 \mathrm{~cm}$} & & $<30 \mathrm{~cm}$ \\
\hline 2015 & & & \multicolumn{2}{|l|}{0.5 points $/ \mathrm{m}^{2}$} & \multicolumn{2}{|r|}{$<20 \mathrm{~cm}$} & & $<30 \mathrm{~cm}$ \\
\hline \multicolumn{9}{|c|}{ Air photographs (source NGI) } \\
\hline Year & Scale & & Resolution (cm) & RMSE X,Y (cm) & Year & Scale & Resolution $(\mathrm{cm})$ & $\begin{array}{l}\text { RMSE } \\
\mathrm{X}, \mathrm{Y} \\
(\mathrm{cm})\end{array}$ \\
\hline 2002 & $1 / 30000$ & & $56-100$ & 112 & 2010 & $1 / 20000$ & 25 & $\leq 50$ \\
\hline 2005 & $1 / 30000$ & & 45 & $\leq 100$ & 2014 & $1 / 20000$ & 25 & $\leq 50$ \\
\hline 2008 & $1 / 20000$ & & 25 & $\leq 50$ & 2017 & $1 / 20000$ & 25 & $\leq 50$ \\
\hline
\end{tabular}

RMSE is the root-mean-square error

${ }^{a}$ The DSM after point cloud transformation had a spatial resolution of $0.5 \mathrm{~m}$, and a Limit of Detection (LoD) of $0.5 \mathrm{~m}$

few small areas, places apparent changes in elevation were caused by changes in the height of the herbaceous vegetation, which varied according to the time of year and meteorological conditions over the preceding months. In such cases, where the effect of vegetation was clear, the relevant pixels were removed from the analysis.

DEMs were also obtained from LiDAR surveys on June 30th, 2010, and September 7th, 2015 (NGI, Instituto Geográfico Nacional) (Table 3), although their resolution was lower than for the UAV images. Four sets of orthophotos, taken from 2008 to 2017, lower-resolution orthophotos from 2005, and rectified air photographs from 2002, were also used in the study to provide additional insights into cliff behavior and to estimate longer-term rates of cliff retreat in this area (Table 3); all air photographs and orthophotos were obtained from the NGI.

Positive (seaward advance) and negative (landward advance) changes in the position of the cliff top were measured for the entire study area. This was accomplished using the Digital Shoreline Analysis System (DSAS) tool in ArcGIS 10.5 and orthophotos digitized to a scale of 1:500, which provided a suitable degree of detail for accurate 
measurement. Changes were recorded with reference to the distance of the cliff top from a baseline generated automatically in the beach area; these distances were measured along 320 transects spaced at $5 \mathrm{~m}$ intervals along the coast. Changes were recorded over various periods since 2002, using as a common endpoint the location of the cliff edge (cliff top) on the high-resolution UAV images of 2018. Three shoreline change parameters were calculated for each transect: the net shoreline movement (NSM), the change in cliff top location from the beginning to the end of a given period of time (while debris from cliff erosion can extend the shoreline seawards, the effect is temporary and is contrary to the permanent landward retreat of the cliff top due to erosion); the End Point Rate or EPR, an annual rate of change derived by dividing the NSM by the number of years in a record; and the Linear Regression Rate (LRR), obtained by fitting a least-squares regression line to all the shore location/time data (Sytnik et al. 2018; Himmelstoss et al. 2018; USGS 2018). The EPR is largely used in this paper for discussion and comparative purposes.

One of the most characteristic elements of coastal cliffs, as viewed in vertical imagery, is their width, defined as the horizontal distance between the location of the slope summit and base. The UAV survey data were used to record positive and negative changes in this parameter, between 2016 and 2018. This required additional measurements to be made to locate the toe of the slope, using the same technique and the same transects as for the cliff top.

A variety of mechanisms can cause portions of the surface of a cliff face to be lowered or elevated. The use of the terms erosion and deposition is therefore restricted in this paper to situations where it is reasonable to assume the origin of any changes in surface elevation, such as due to wave erosion or the deposition of material at the foot of a cliff. Where the cause is less clear, or attributable to other mechanisms, the non-generic terms surface lowering and surface rising (or their contracted forms lowering and rising) are used instead of erosion and deposition. The terms sector and period are used throughout the paper to refer to specific areas (A, B, C, etc.) and intervals (I, II, III, etc.) between aerial surveys, respectively (Table 1; Fig. 1). Although erosional data are provided for each survey interval (I-VII), the emphasis in this paper is between periods of differing duration that terminate in the more reliable, higher resolution data from 2018 (Table 4). This ensures that, in contrast to comparisons between pairs of earlier surveys (say between periods I and II), at least one end point in each pair (for 2018) can be considered to be a fairly precise representation of shoreline location at that time. Furthermore, differences in mean erosion rates over longer and shorter periods, terminating in 2018, are indicative of erosion rates during the earlier part of the longer period (for example, differences in rates between 2016-2018 and 2010-2018 reflect differences in the rates between 2010-2016 and 2016-2018).

\section{Results}

Because of the large number of data-producing pixels from the UAV images (2016 and 2018), (ranging from approximately 250,000 for sector $E$ to almost 2 million for sector D), non-parametric Spearman Rank and parametric Pearson correlation coefficients ranged from -0.87 to -0.95 and were significant $(p<0.01)$ for the elevation of the cliff face and the distance from the cliff top in each sector. The correlations for the relationship between local gradient and distance from the cliff top were also significant at the $p<0.01$ level, but much lower and more variable between sectors $(-0.24$ to -0.34 for sectors $\mathrm{A}, \mathrm{C}$, and $\mathrm{E}$, and -0.02 to -0.16 for sector D), reflecting the degree of irregularity in the surface of the cliff faces. Although the gradient generally decreased seawards, reflecting a tendency towards profile concavity, it increased in sector B (both correlation coefficients were 0.31 , where a more convex profile had a gently sloping segment near the cliff top and a much steeper slope seaward (Fig. 4, profiles B01 to B03).

The UAV data showed that between 2016 and 2018, approximately $76 \%$ of the cliff face within the 6 sectors experienced measurable lowering (negative values) or rising (positive values), as expressed by vertical changes in each pixel. Most changes in elevation were fairly small, however, and the $-0.36 \mathrm{~m}$ mean value was close to the LoD (Figs. 4, $5,6)$. These changes in elevation on the cliff face produced an overall decrease in volume in the 6 sectors of $4048.16 \mathrm{~m}^{3}$. The highest percentage loss of material occurred in sectors C (53.8\%) and D (71.8\%) which, in the latter case, also had the greatest absolute loss $\left(1403.3 \mathrm{~m}^{3}\right)$, in part due its large surface area. There are several possible explanations for increases in elevation and volume in sectors $\mathrm{A}, \mathrm{E}$, and F, but the most plausible is due to the decrease in density and increase in volume that occurs when intact rock is eroded and deposited in loose, poorly packed accumulations with numerous inter-clast voids. This promotes surface rising over lowering, so that the latter is more likely than the former to be below the LoD, and therefore to be under-reported.

The changes in elevation and volume recorded from the 2016 and 2018 UAV surveys generally reflected the transfer of material from the central to the lower portions of the cliffs (Fig. 2e). Most changes involved increased basal scarping, with an increase in local slope gradient, by wave erosion at the foot of the cliffs (Fig. 4, profile A02, Fig. 5, profile D04), or the burial and elimination of cliff foot scarps by the further deposition of slope material, resulting in a decrease in local slope gradient (Fig. 4, profile B01; Fig. 6, profile F02). 
Table 4 Rates of cliff recession $\left(\mathrm{m} \mathrm{yr}^{-1}\right)$

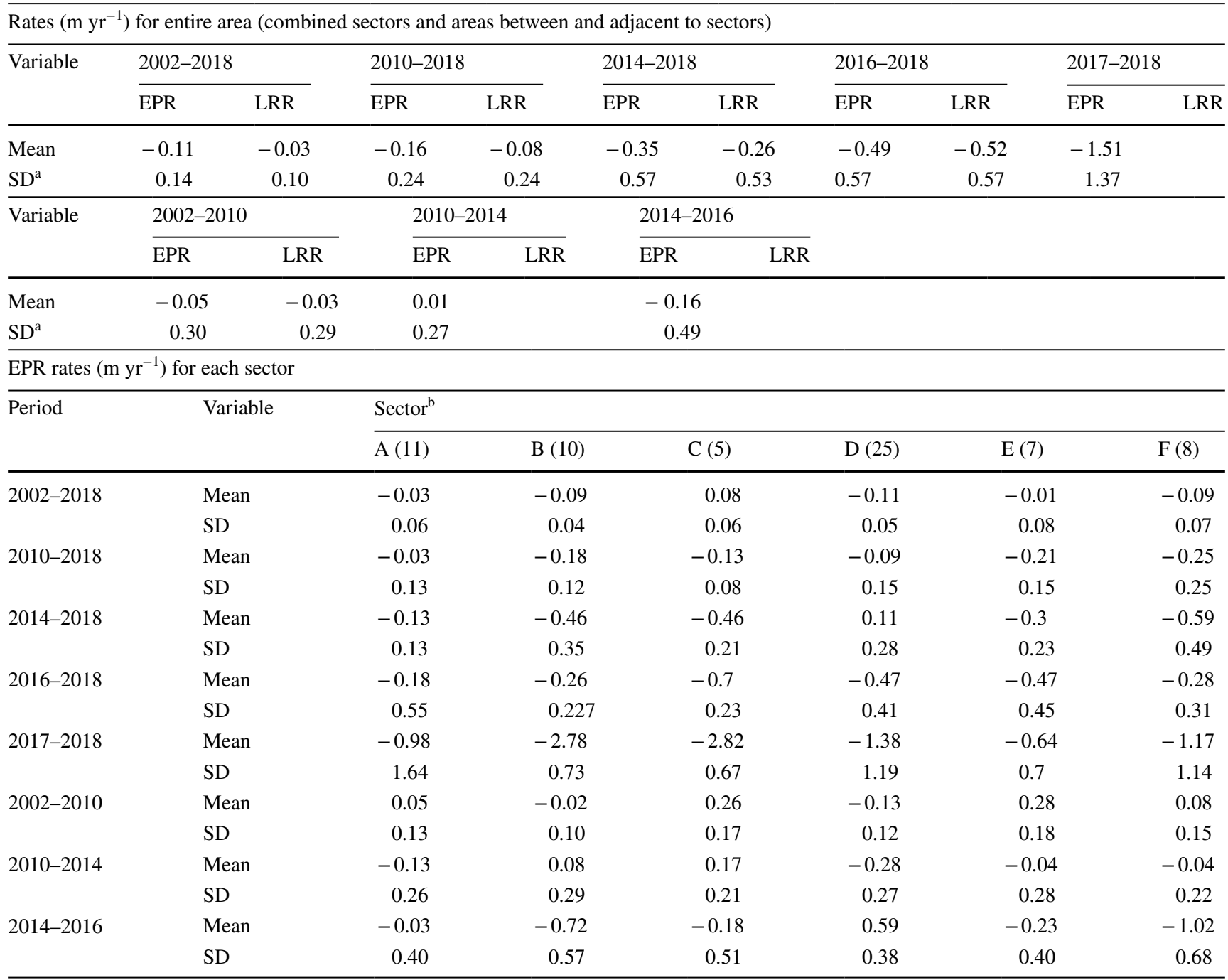

${ }^{\text {a }} \mathrm{SD}$ refers to the standard deviation

${ }^{\mathrm{b}}$ The number in parentheses after each sector number letter refers to the number of transects in each sector

Although the resolution was much lower than in the UAV surveys, a similar analysis was conducted on the DEMs constructed from LiDAR data from 2010 and 2015. The general shape of the UAV and LiDAR cliff profiles was similar, but there were some significant differences in the distribution of areas of surface rising and lowering in each sector. In comparison with the UAV surveys for 2016-2018, the 2010-2015 LiDAR data suggested that there was previously: less lowering and more rising at the cliff foot in sector A; more rising and less lowering in the upper cliff and less rising at the cliff foot in sector B; rising instead of lowering in the upper cliff in sector $\mathrm{C}$; dominance of rising over lowering in sector D; rising instead of lowering in the lower cliff and lowering instead of rising in the upper cliff in sector $\mathrm{E}$; and dominance of low amounts of rising over almost the entire cliff face in sector $\mathrm{F}$.
For the entire area, including the sectors and the areas lying between and adjacent to them, mean annual rates of cliff erosion over the extended study period (2002-2018) ranged between 0.11 and $1.51 \mathrm{~m} \mathrm{yr}^{-1}$ for the EPR and from 0.03 to $0.52 \mathrm{~m} \mathrm{yr}^{-1}$ for the LRR. The most accurate measurements were probably those from 2016 to 2018 , however, due to the high resolution of the UAV data, and these suggested recent rates of about $0.5 \mathrm{~m} \mathrm{yr}^{-1}$ (Table 4; Fig. 7).

The mean EPR was consistently low for each sector over the 2002-2018 period, ranging from $0.01 \mathrm{~m} \mathrm{yr}^{-1}$ in sector E to $0.11 \mathrm{~m} \mathrm{yr}^{-1}$ in sector D. Rates increased progressively through time, although they occasionally declined temporarily from one period to the next in individual sectors. There was no consistent pattern in the sectors which recorded the highest and lowest rates of erosion during each period. Rates determined from the high-resolution data of 2016 and 2018 

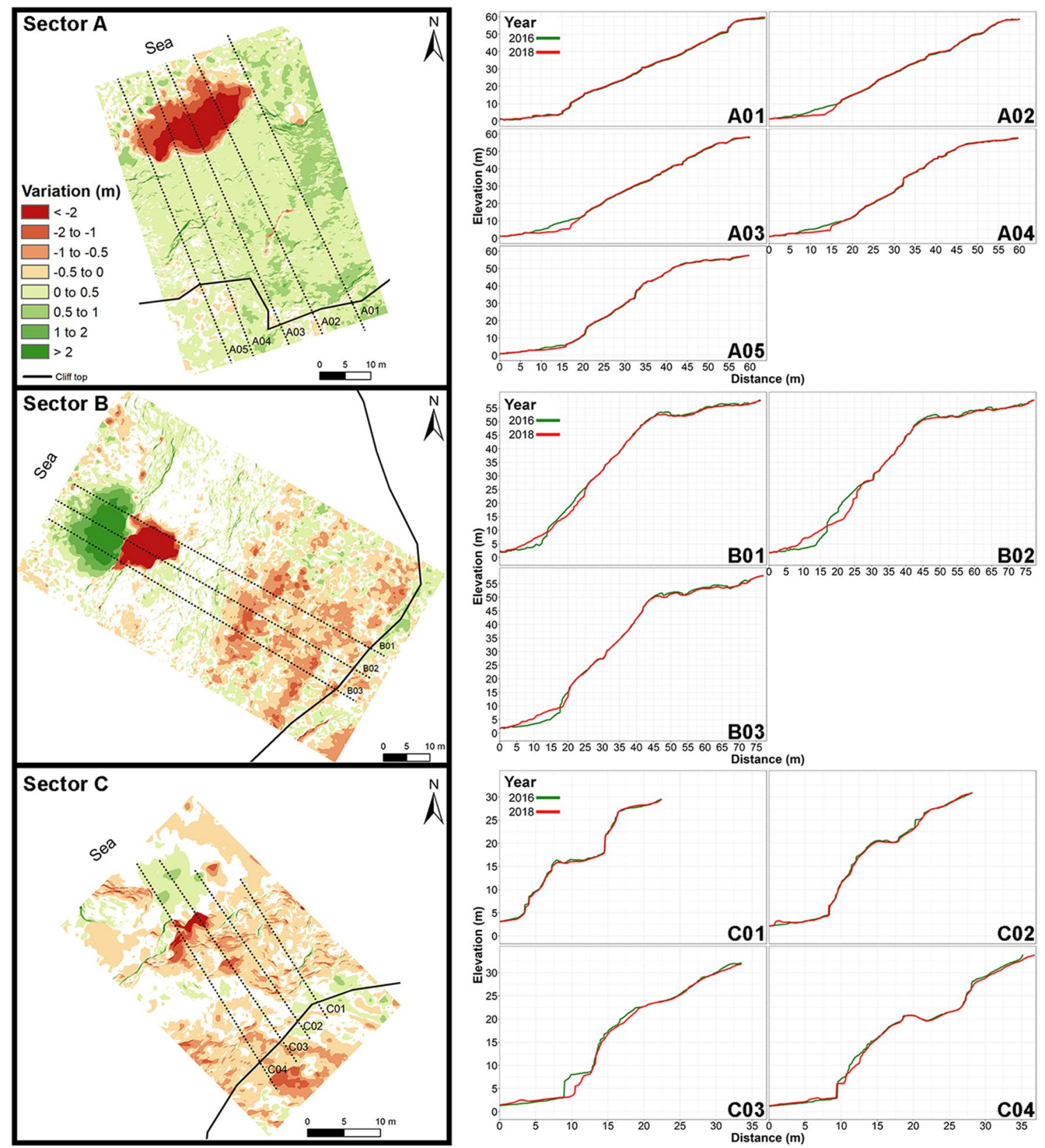

Fig. 4 Maps and profiles showing changes in elevation in sectors A, B, and C from the 2016 to the 2018 survey. White areas on the maps had values below the LoD between -0.2 and $0.2 \mathrm{~m}$

were much greater than in the earlier parts of the extended study period, ranging from a high of almost $0.5 \mathrm{~m} \mathrm{yr}^{-1}$ in sectors $\mathrm{D}$ and $\mathrm{E}$ to a low of $0.18 \mathrm{~m} \mathrm{yr}^{-1}$ in sector A. Even higher rates of recession were recorded from 2017 to 2018, although they were based in part on lower-resolution orthophotos from 2017 (Table 4).

Apart from an area immediately east of sector D, there were no strong regional patterns in cliff recession rates at the individual transect scale. Along the rest of this coast rates varied significantly over short distances, and between adjacent transects, producing a distribution that appeared essentially chaotic in nature (Fig. 7). Transect rates of retreat were frequently from 0 to $<0.01 \mathrm{~m} \mathrm{yr}^{-1}$ in the earlier part of the 2002-2018 period, but they had increased to $>0.02 \mathrm{~m} \mathrm{yr}^{-1}$ at most transect sites by about 2016, or somewhat earlier, and these rates became increasingly dominant up to 2018. Increases in transect rates of erosion were, therefore, consistent with the trends that were evident in the mean rates at the study area and sector scales (Table 4). 


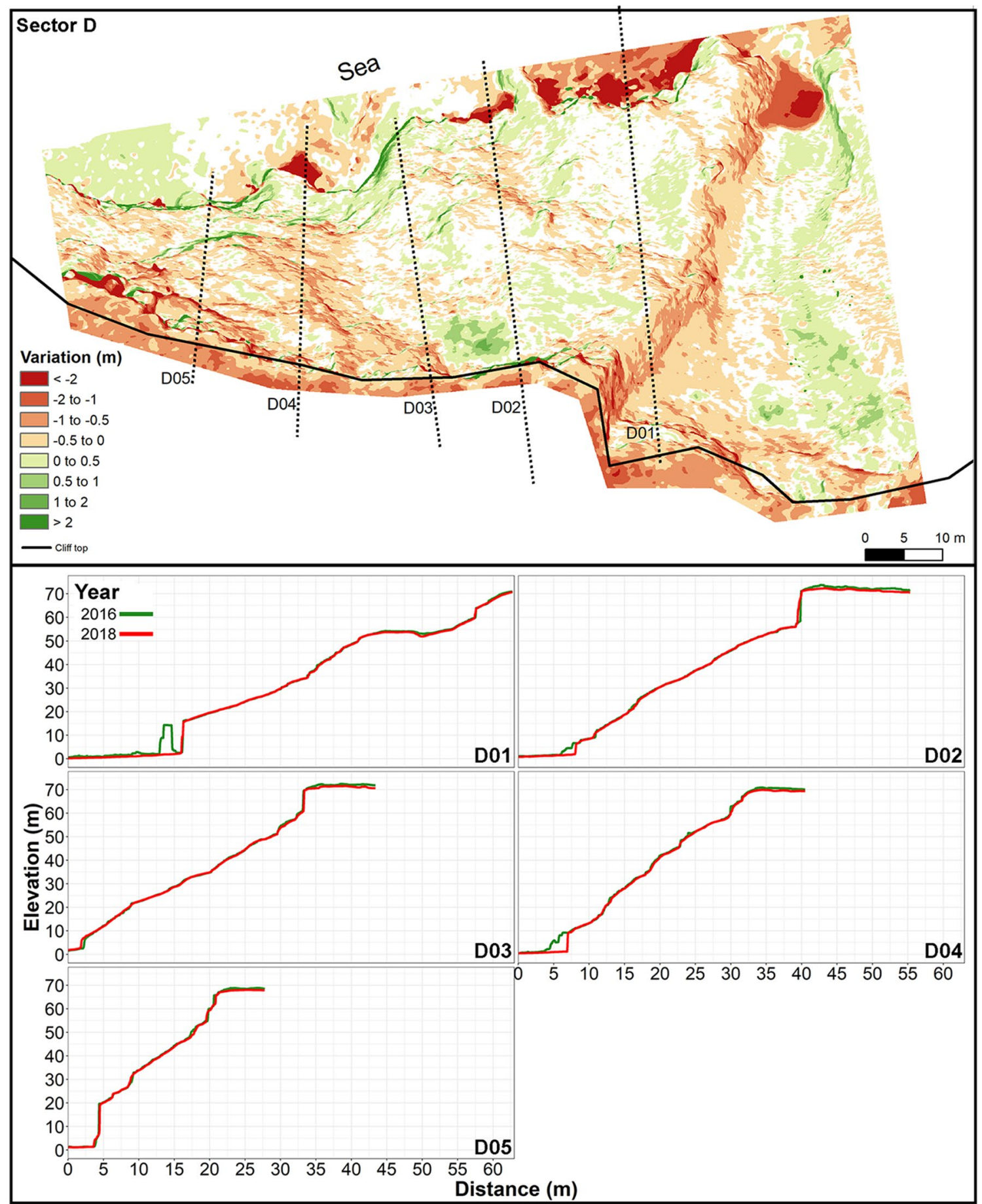

Fig. 5 Map and profiles showing changes in elevation in sector D from the 2016 to the 2018 survey. White areas on the map had values below the LoD, between -0.2 and $0.2 \mathrm{~m}$

The mean change in the width of the cliff face for the entire 320 transects within and between the 6 sectors, and to the immediate east of sector A, was $-0.09 \mathrm{~m}$, signifying a small decrease in width over this two-year period (2016-2018), with recession at the cliff top being slightly less than erosion of intact rock or removal of loose debris at the cliff foot. Changes in cliff face width varied considerably in amount and direction with location along the study area, however, with significant increases in width in sector $\mathrm{A}$ and between sectors $\mathrm{E}$ and $\mathrm{F}$, and much greater reductions in width in sectors $\mathrm{B}$ and $\mathrm{F}$ (Table 5). 

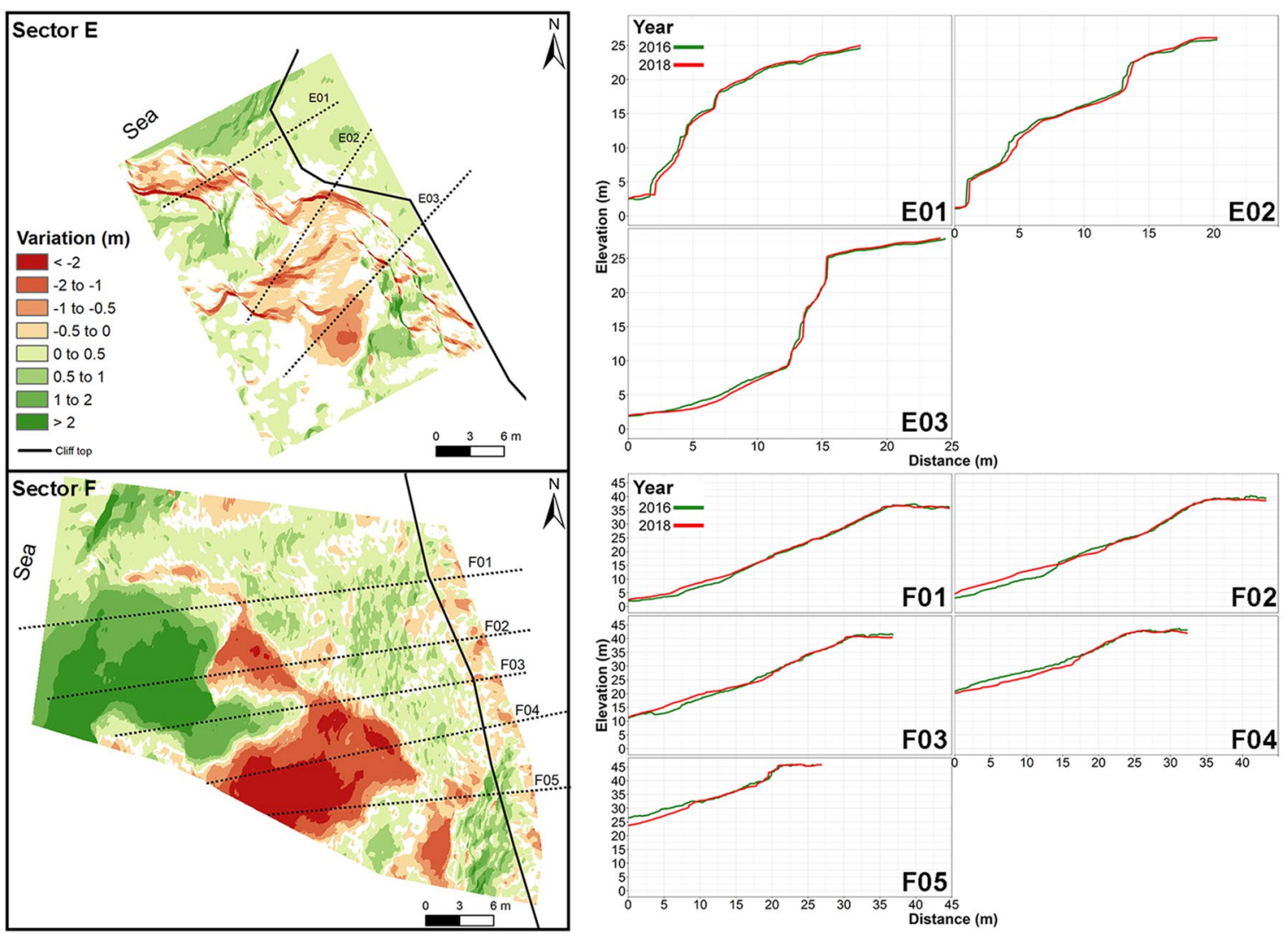

Fig. 6 Maps and profiles showing changes in elevation in sectors E and F from the 2016 to the 2018 survey. White areas on the maps had values below the LoD, between -0.2 and $0.2 \mathrm{~m}$

Changes in mean cliff face width could be the result of a small number of large changes in the upper or lower boundaries of the cliff face, or of a large number of small changes. Standard deviations were broadly similar for most of the sectors and extra-sector areas in the study (Table 5), being frequently roughly equal or greater than the mean change in width in each location. There was a particularly high value in sector $F$ due to the addition and depletion of significant amounts of landslide debris from the foot and the lower part of the cliff (Figs. 2c, 6, profiles F01-F05), and a low value in the area immediately east of sector $\mathrm{A}$.

The images were also used to map and record the occurrence of mass movements, primarily landslides, between 2002 and 2018. Movements that were large enough to be identified were recorded for each period, for areas within and adjacent to the study sectors. Most slides were restricted to the lower part, rather than the whole, of a cliff face (Fig. 2), although a few did extend from near the top to the bottom of the slope. Slides were most frequent from 2008 to 2010 (18 events), and 2016 to 2018 (21 events), and least common between 2010 and 2014 (5 events). Movements occurred in all six sectors and in the areas between the sectors between 2002 and 2018 but were least frequent in sectors $\mathrm{A}$ and $\mathrm{C}$ ( 1 event in each sector) and to a lesser extent in sector F ( 3 events).

There was little relationship between rates of cliff recession and a variety of meteorological conditions. Furthermore, while there is evidence to suggest that cliff recession may have accelerated through time, being fastest from 2016 to 2018 and especially 2017 to 2018 (Table 4), this increase was not matched by increases in annual rainfall (Fig. 3c), storm frequency or intensity, (Table 2), or soil moisture (Fig. 3d).

\section{Discussion}

The profiles of rocky cliffs have been characterized as essentially passive expressions of elevational differences in erosional susceptibility to marine and subaerial processes (Emery and Kuhn 1982). Cliffs also function as transportation systems, as a component of the rock cycle that delivers the products of erosion and weathering to the upper intertidal zone, where they can be removed by waves. There is a continuum of transportational cliff types defined according to the time that debris is stored at the cliff foot, thereby 
Fig. 7 Negative (cliff retreat) and positive (cliff advance) changes for each transect from 2016-2018 (top) and 20022018 (bottom) (2002 air photo and 2016 and 2018 UAV data)
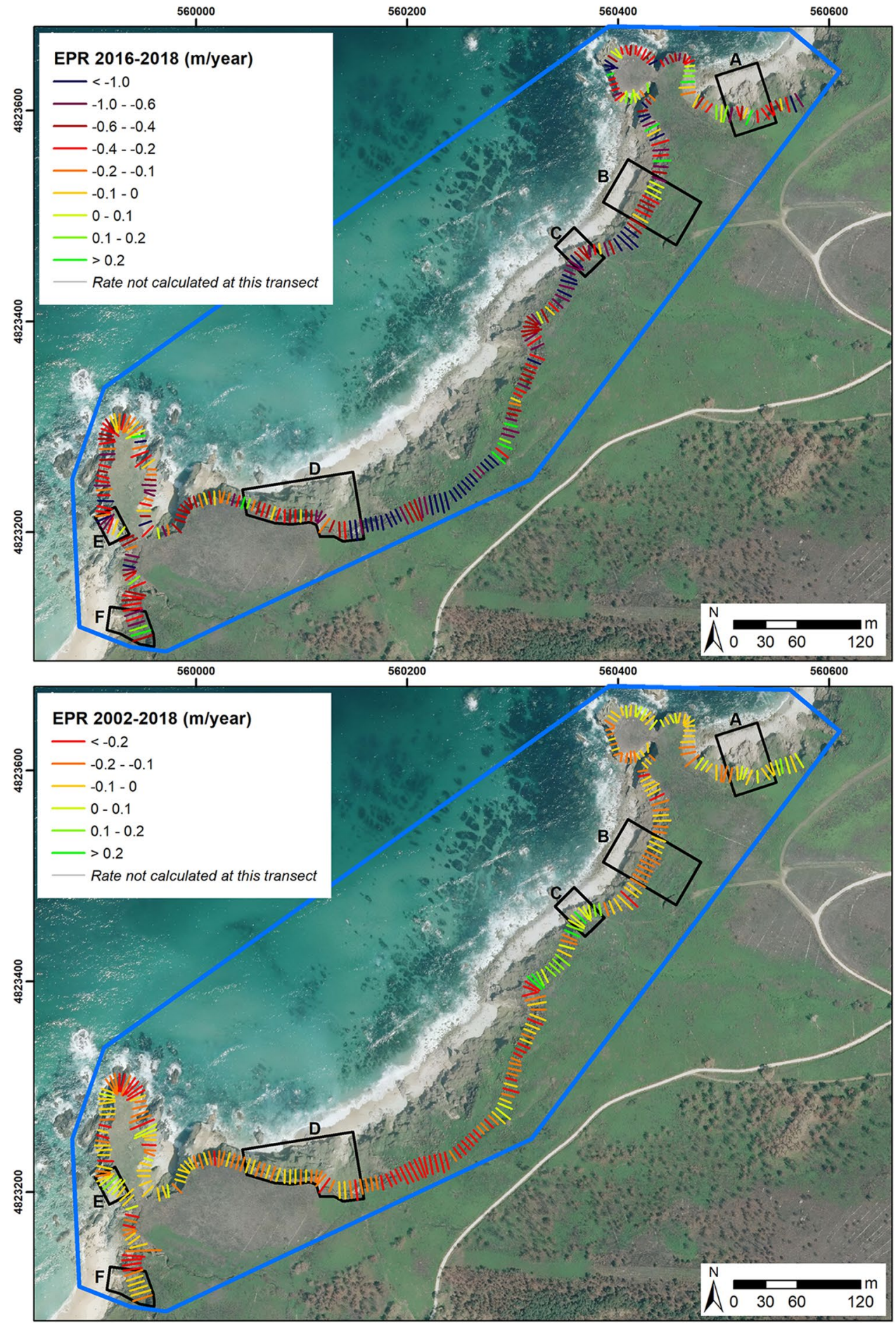

Location relative to sectors ${ }^{\mathrm{a}}$ of the cliff face (cliff top cliff foot) by sector from 2016 to 2018 (UAV surveys)

\begin{tabular}{lllllllllllll}
\hline & East of A & A & A-B & B & B-C & C & C-D & D & D-E & E & E-F & F \\
\hline No. of transects & 7 & 11 & 73 & 10 & 13 & 5 & 73 & 25 & 72 & 7 & 16 & 8 \\
Change in width $^{\mathrm{b}}$ & 0.47 & 2.11 & 0.16 & -5.34 & -1.68 & 0.18 & 0.39 & -0.67 & 0.26 & 0.27 & 1.47 & -5.92 \\
SD & 0.19 & 1.45 & 0.70 & 1.51 & 1.65 & 0.95 & 1.12 & 1.71 & 0.54 & 0.66 & 1.57 & 2.82 \\
\hline
\end{tabular}

${ }^{\mathrm{a}} \mathrm{A}-\mathrm{B}$ refers to the area lying between sectors $\mathrm{A}$ and $\mathrm{B}$ and so on

${ }^{\mathrm{b}}$ Positive values signify increases in width and negative values decreases in width $(\mathrm{m})$ 
protecting it from wave erosion. At the one end are sloping, transport-limited (TL) cliffs that are covered in debris and no longer being eroded by, the sea (Fig. 8a). This condition could arise through a fall in relative sea level, the protection afforded by the growth of a fronting barrier or pebble beach, or construction of breakwalls or other human infrastructure. At the other end are steep, supply-limited (SL) cliffs where the rapid disposal of fallen debris inhibits sediment storage and permits essentially continuous wave erosion of the cliff base. These cliffs may develop where there are high waves, mobile, fine-grained debris, or slow debris production (Fig. 8b).

Between the TL and SL extremes are cliffs which for convenience will be termed periodically transport-limited (pTL) a Transport-limited (TL), no wave removal allows debris accumulation and slope burial

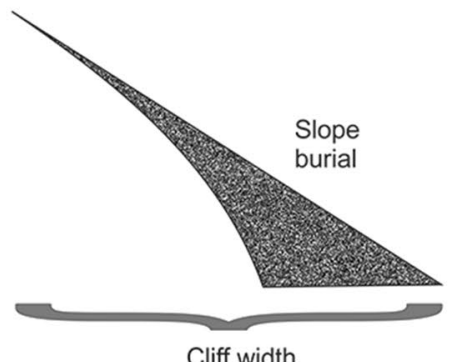

Cliff width b Supply-limited SL), no persistent debris storage (strong waves, mobile, fine-grained material, slow debris production

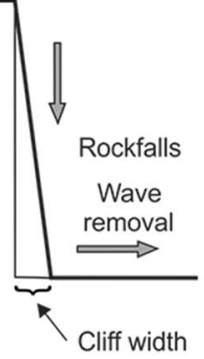

c Periodically transport-limited ( $p T L$ ), cyclical storage of debris (episodic cliff/notch collapse)

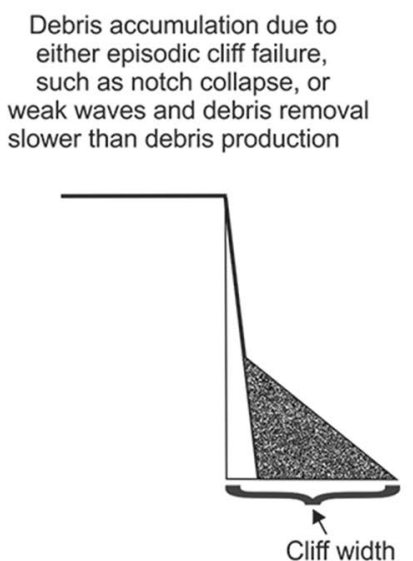

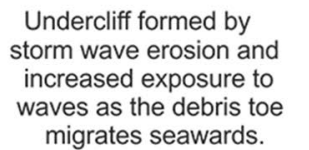

storm wave erosion and

reased exposure to

migrates seawards.

Instability generates landslides

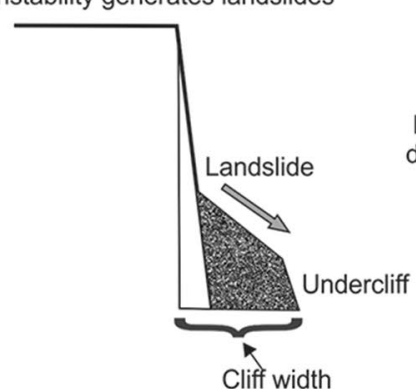

Removal of landslide

debris and renewed

cliff/notch erosion

until next collapse event

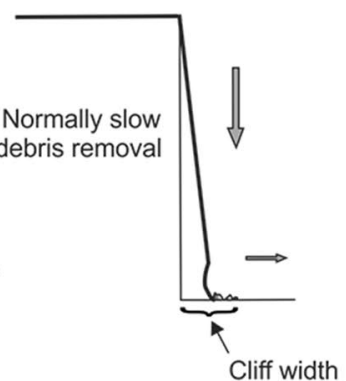

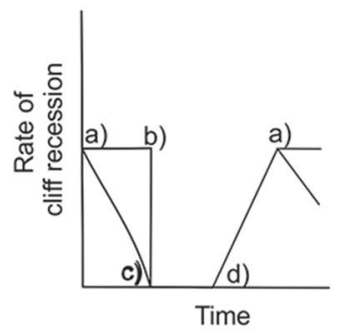

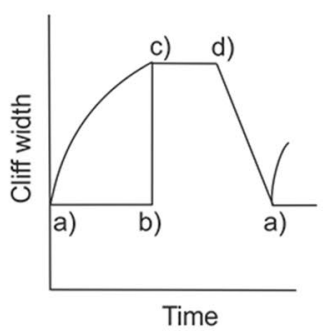

a)-b)-c) uniform erosion followed by collapse of the cliff face or a)-c) gradual reduction in erosion with buildup of debris and increasing protection of the cliff foot/notch. Debris buildup increases cliff width.

c)-d) Complete protection of the cliff foot, with no erosion.

d)-a) gradual increase in cliff erosion and decrease in cliff width as debris is removed

Fig. 8 Coastal cliff transportation systems distinguished according to the time talus is able to protect the cliff foot before being removed 
in this paper. These cliffs experience cyclical development including periods when the cliff foot is exposed and periods when it is protected by talus from wave erosion (Fig. 8c). These types of cliff are cascading systems whereby weathering and oversteepening by waves deliver debris from the cliff face to the cliff foot. This material accumulates, at its angle of repose, until undercut and steepened by wave action, in single or multiple storm events, destabilizing the deposit and promoting its removal by landslides and wave action (McLean and Davidson 1968; Castedo et al. 2017; Trenhaile 2020). In some areas, debris removal may also be facilitated by increasing exposure to wave action as the toe of a growing talus migrates seawards. Talus deposits can result from abrupt and catastrophic cliff failures, the more gradual addition of individual rock fragments with high transport (disposal) thresholds (due to debris size and shape), or low transport capacity and competency in weak or protected wave environments. In addition to talus-dominated periods of transport limitation, pTL cliffs can also be periodically $\mathrm{SL}$ in some fairly resistant rocks. This occurs when sediment production essentially ceases, or is maintained at a very low level, while a notch is cut to its maximum supportable depth. SL and TL conditions can also operate simultaneously on pTL cliffs consisting of a variety of rock types. This can occur, for example, where there are alternating beds of limestone and shale, with the latter shedding fine, easily disposable material while thick, structurally strong limestones provide the roofs for deep undercuts and, upon collapse, large debris accumulations (Trenhaile 1972).

Assuming fairly homogeneous geological and morphogenic (waves, tides, etc.) conditions, cliff recession rates and cliff face width would slowly decline to almost zero on TL cliffs, and be quite uniform in SL environments, albeit punctuated by chaotic perturbations, and therefore fairly predictable over time (Fig. 8a and b). Conversely, there are likely to be marked variations in cliff morphology and rates of erosion in pTL environments. The decline in cliff recession rates would vary according to the rate of debris accumulation, for example, ranging from a gradual reduction due to the addition of individual clasts to an abrupt cessation caused by a sudden, catastrophic slope failure. Similarly, changes in cliff width would mirror the rate of talus growth, with maximum width being attained when the talus extended furthest seawards. Cliff recession would then be essentially zero during the time required to remove the debris, and to destabilize the cliff (Trenhaile 2014b, 2020) (Fig. 8c).

The predominance of talus suggests that the cliffs in the study area are primarily pTL, although there is also a SL component due to the supply and rapid disposal of small rock fragments at their foot. A distinction can be made, however, between pTL cliffs in the bay that are in different stages of development. In the north, around sector B, the cliffs have talus deposits at their foot, whereas those in the south are essentially bare rock faces with a prominent notch under sectors $\mathrm{C}$ and D (Figs. 1c, 2d). While the entire bay is well exposed to storm waves from the northwest, wave attenuation over the intertidal and subtidal shore platform in the north is likely to be much greater than over the narrower and predominantly sandy beaches in the south (Fig. 1c and d). While strong waves promote cliff undercutting and collapse, the dominance of notches and steep, bare cliffs in the south suggests that, while talus periodically protects the cliff foot, it is removed much faster than it is produced. Conversely, in the north, more attenuated waves may result in slower cliff erosion and debris removal, with the predominance of talus in this area suggesting that debris removal operates more slowly than debris production.

The erosional data provided conflicting evidence of the effect of talus accumulations at the cliff foot (Table 4). While the lack of talus may have contributed to faster erosion in sectors C and D than in sector B from 2016 to 2018, for example, erosion was faster in sector B than in the other two sectors from 2014 to 2016. In addition to the opposing effects of talus accumulation and wave attenuation rates in these sectors, the lack of consistent relationships between talus deposition and rates of cliff erosion may be attributed to the low temporal resolution of the erosional data and the lack of correspondence between survey intervals and the duration of debris accumulation and removal cycles, resulting in cliff recession rates that are dependent, in part, on when the survey was conducted.

The sectors outside the bay are sheltered from northwesterly storm waves by the two headlands (Fig. 1), and by: a boulder and cobble beach and a wide, largely submarine shore platform in sector A; a sand and boulder beach in sector E; and a wide sandy beach in sector F. The lower part of the cliffs in sectors $A$ and $F$ is draped in debris in various stages of removal, which is consistent with the assumption that debris accumulation and removal are dominant where there is weaker wave action. This assumption must be tempered by the occurrence of an essentially bare and exposed cliff face in section E, however, which may be the least exposed to vigorous wave action in the study area. There are several possible explanations which may account for the lack of talus in this sheltered area, including the occurrence of a porphyritic granite dike which releases fine, easily transported material, and a $24 \mathrm{~m}$-high cliff which produces less debris than the much higher cliffs elsewhere in this region.

An important question regarding the development of rock coasts, which also has implications for coastal management and planning for climate change, is whether the plan shape of irregular, crenulated (headland and bay) coasts trends towards a state of dynamic equilibrium. This possibility is based on the assumption that, as an irregular coast develops, erosion of the more resistant rocks on headlands by increasingly refracted waves must eventually accomplish the 
same amount of erosion as the weaker, attenuated waves on the less resistant, and often beach-protected, rocks in bays (Muir-Wood, 1971; Trenhaile 1987, pp. 269-270; 2002; 2019)

There is no evidence that the plan shape of the Galician coast was in equilibrium over the short periods covered in the present study (Table 4). Rates of cliff recession in some sectors were commonly several times greater than in other sectors, even over the 2016-2018 period covered by highresolution UAV imaging. There was no consistent pattern in the occurrence of sectors with particularly high or low recession rates, with the possible exception of persistently lower values in zone A, which is more sheltered from storm waves than most other sectors. There was also little evidence of plan shape equilibrium at the transect scale, for the sectors and areas adjacent to, or between, the sectors. The largest area with essentially uniform cliff recession rates was at the rear of the shallow bay east of sector D, which exhibited relatively rapid retreat in the 2002-2018 and 2016-2018 periods (Fig. 7). The most prominent headlands in the study areas, between sectors $A$ and $B$ in the north and D and $E$ in the south, experienced a range of recession rates that were lower than in the C-D bay from 2016 to 2018, although rates were comparable between the tip of the southern headland and the C-D bay from 2002 to 2018 .

The lack of evidence for plan shape equilibrium is not surprising given the limited time covered in this study and the cyclical pTL nature of coastal development in this area. Under such circumstances, it is likely that any effect of differences in wave height and rock resistance between headlands and bays would be obfuscated by the influence of other factors, including the protection or enhanced erosion (through abrasion) afforded by beach material (Limber et al. 2014; Limber and Murray 2014; Trenhaile 2016), the drainage and water-holding characteristics of the rock, and possibly changes in sea level and storminess.

Landslides and other mass movements can be triggered by high pore water pressures produced during periods of heavy rainfall or snowmelt (Polemio et al. 2000; Duperret et al. 2005; Massey et al. 2013; Gordo et al. 2019; Li et al. 2019). There is limited evidence of this effect in northwestern Galicia, despite reports in the local press of landslides occurring during winter and spring (Abelairas 2017), including one in sector F in March 2017, following a period when $87.4 \mathrm{~mm}$ of rain fell over 10 days (Meteogalicia 2020). The general lack of a relationship between rates of cliff retreat and annual to daily rainfall and groundwater data in this area (Fig. 3c and d) might be attributed to the poor temporal resolution of the data. The function of most of the slides described in this paper is to transport and help to dispose of previously dislodged and fallen debris, however, rather than to contribute directly to the erosion of intact rock. Furthermore, while heavy rainfall may help to trigger landsliding in the talus deposits, this might be accomplished more effectively by the splash and spray of large storm waves as they simultaneously erode and destabilize the debris toe. Therefore, heavy, or prolonged rainfall may not be the primary driving force for the landslides along this coast.

The coast of northwestern Galicia experiences pTL conditions, with cascading systems operating on the cliff face and on the talus deposits below. Cyclical behavior, therefore, results in different parts of the study area being at different stages of development at the time of each survey. Asynchronous behavior must account, in part, for the spatial and temporal variations in cliff recession rates and cliff width reported in this paper. Although it is difficult, due to wide spatial and temporal variations, and essentially stochastic behavior, to correlate global rates of cliff recession with such intuitively important variables as climate, wave regimes, and rock hardness and structure, values around $0.03 \mathrm{~m} \mathrm{yr}^{-1}$ may be considered characteristic of resistant rocks, $0.10 \mathrm{~m} \mathrm{yr}^{-1}$ of moderately resistant rocks, and $0.23 \mathrm{~m} \mathrm{yr}^{-1}$ of low resistance rocks (Prémaillon et al. 2018; Stephenson et al. 2021). The data discussed in this paper, therefore, suggest that recession rates in the weathered rocks of the study area are broadly characteristic of rocks of similar resistance in other areas. Recent rates, since 2016, are particularly rapid, however, and may reflect, not only the fractured nature of the rocks, but also the exposed nature of this coast and its vigorous wave environment.

It has been suggested that cliff erosion rates will increase due to rising sea level and possibly increased storminess (Dickson et al. 2007; Ashton et al. 2011; Trenhaile 2011, 2014a; Gómez-Pazo and Pérez-Alberti 2017; Limber et al. 2018), but the data from hard rock coasts are, at present, ambiguous and contradictory (Lee et al. 2001; Hurst et al. 2016; Young 2018; Swirad et al. 2020). There is little evidence that apparently increasing rates of recession in the study area were triggered by increases in wave height or precipitation, and it is questionable whether such a marked increase in rates could be attributed to an approximately $0.06 \mathrm{~m}$ rise in global sea level from 2002 to 2018 (Table 4; Fig. 3b and c) (NASA 2020). Consequently, lacking specific evidence to the contrary, one can only conjecture at present that any increase in the rate of cliff recession in this area is the result of perturbations related to cyclical variations in geomorphological activity. Determining whether these cycles are experiencing, and being modified by, the effects of rising sea level and other elements of climate change, which could account for a consistent increase in recession rates with time, will require longer erosional records from the study area and from similar rock coasts than is presently available. 


\section{Conclusions}

Images obtained from UAVs, supplemented by a series of aerial photographs and aerial LiDAR, were used to study rocky cliff evolution from 2002 to 2018 in northwestern Galicia, Spain. The main conclusions of this research are as follows:

a) Cliffs migrate landwards in cycles characterized by a series of stages involving rockfalls, talus sediment storage, destabilization through wave undercutting and landsliding, and renewed cliff exposure and erosion.

b) Cliff recession rates vary in time and space due to changing conditions within a cycle and the time when a survey is conducted.

c) The data suggest that rates of cliff recession have been progressively increasing during the study period.

d) There was no evidence of plan shape equilibrium between headlands and bays in this area; and

e) Coastal landslides, which are disposal mechanisms for talus deposits fallen from the steep cliff face, are triggered by wave erosion and probably storm wave spray and splash, rather than by heavy rainfall.

Acknowledgements This work was supported by CRETUS Institute. Alejandro Gómez-Pazo was in receipt of an FPU predoctoral contract from the Spanish Ministry of Education and Innovation with reference FPU16/03050. The authors thank Maxim Bogdanowitsch and a second, anonymous reviewer for their helpful comments and suggestions.

Author contributions Conceptualization, AP-A, AG-P and A; methodology, AG-P and AT; formal analysis, AG-P and AT; investigation, AP-A, AG-P and AT; writing - original draft preparation, AP-A, AG-P and AT; writing - review and editing, AP-A, AG-P and AT. All authors have read and agreed to the published version of the manuscript.

Funding Open Access funding provided thanks to the CRUE-CSIC agreement with Springer Nature. The work of A.G-P is supported by and predoctoral contract from Spanish government (Ministerio de Educación, Cultura y Deporte). Gran Number: FPU16/03050.

Availability of data and material Not applicable.

Code availability Not applicable.

\section{Declarations}

Conflict of interest The authors declare no conflict of interest.

Ethics approval Not applicable.

Consent to participate Not applicable.

Consent for publication Not applicable.
Open Access This article is licensed under a Creative Commons Attribution 4.0 International License, which permits use, sharing, adaptation, distribution and reproduction in any medium or format, as long as you give appropriate credit to the original author(s) and the source, provide a link to the Creative Commons licence, and indicate if changes were made. The images or other third party material in this article are included in the article's Creative Commons licence, unless indicated otherwise in a credit line to the material. If material is not included in the article's Creative Commons licence and your intended use is not permitted by statutory regulation or exceeds the permitted use, you will need to obtain permission directly from the copyright holder. To view a copy of this licence, visit http://creativecommons.org/licenses/by/4.0/.

\section{References}

Abelairas B (2017) Landslide in the Ponzos nudist area. La Voz de Galicia, A Coruña, Galicia

Alessio P, Keller EA (2020) Short-term patterns and processes of coastal cliff erosion in Santa Barbara. California Geomorphol 353:106994. https://doi.org/10.1016/j.geomorph.2019.106994

Arbanas SM, Komac M, Gokceoglu C, Paulin GL (2014) Introduction: landslide inventories and databases. In: Sassa K, Canuti P, Yin Y (eds) Landslide science for a safer geoenvironment. Springer, Heidelberg, pp 783-785. https://doi.org/10.1007/9783-319-05050-8_120\#

Ashton AD, Walkden MJA, Dickson ME (2011) Equilibrium responses of cliffed coasts to changes in the rate of sea level rise. Mar Geol 284(1-4):217-229. https://doi.org/10.1016/j. margeo.2011.01.007

Blanco Chao R, Pérez Alberti A (1996) Coastal forms on the northwestern Galician coast: The cliff sectors between Cabo Prioriño (Ferrol) and Punta Frouxeira (Valdoviño). Geographicalia 33:328. https://doi.org/10.26754/ojs_geoph/geoph.1996331708

Buchanan DH, Naylor LA, Hurst MD, Stephenson WJ (2020) Erosion of rocky shore platforms by block detachment from layered stratigraphy. Earth Surf Process Landforms 45:1028-1037. https://doi.org/10.1002/esp.4797

Castedo R, Paredes C, de la Vega-Panizo R, Santos AP (2017) The modelling of coastal cliffs and future trends. In: Shuklar DP (ed) Hydro-geomorphology_models and trends. Intechopen, London. https://doi.org/10.5772/intechopen.68445\#

Del Río L, Gracia FJ (2009) Erosion risk assessment of active coastal cliffs in temperate environments. Geomorphology 112:82-95. https://doi.org/10.1016/j.geomorph.2009.05.009

Dickson ME, Walkden MJA, Hall JW (2007) Systemic impacts of climate change on an eroding coastal region over the twentyfirst century. Clim Change 84:141-166. https://doi.org/10.1007/ s10584-006-9200-9

Duperret A, Taibi S, Mortimore RN, Daigneault M (2005) Effect of groundwater and sea weathering cycles on the strength of chalk rock from unstable coastal cliffs of NW France. Eng Geol 78:321-343. https://doi.org/10.1016/j.enggeo.2005.01.004

Emery KO, Kuhn GG (1982) Sea cliffs: their processes, profiles, and classification. GSA Bull 93:644-654. https://doi.org/10.1130/ 0016-7606(1982)93\%3c644:SCTPPA\%3e2.0.CO;2

Esposito G, Salvini R, Matano F, Sacchi M, Danzi M, Somma R, Troise C (2017) Multitemporal monitoring of a coastal landslide through SfM-derived point cloud comparison. Photogramm Rec 32:459-479. https://doi.org/10.1111/phor.12218

Gómez-Pazo A, Pérez-Alberti A (2017) Vulnerability of the Galician coast to marine storms in the context of global change. SÉMATA, Cienc Soc Hum 29:117-142

Gordo C, Zêzere JL, Marques R (2019) Landslide susceptibility assessment at the basin scale for rainfall- and 
earthquake-triggered shallow slides. Geoscience 9(6):268. https://doi.org/10.3390/geosciences9060268

Himmelstoss EA, Henderson RE, Kratzmann MG, Farris AS (2018) Digital shoreline analysis system (DSAS) version 5.0 user guide: U.S. geological survey open-file report 2018-1179. U.S. Geological Survey, Reston, VA, pp 110. https://doi.org/10.3133/ ofr20181179.

Horacio J, Muñoz-Narciso E, Trenhaile AS, Pérez-Alberti A (2019) Remote sensing monitoring of a coastal-valley earthflow in northwestern Galicia, Spain. CATENA 178:276-287. https:// doi.org/10.1016/j.catena.2019.03.028

Hurst MD, Rood DH, Ellis MA, Anderson RS, Dornbusch U (2016) Recent acceleration in coastal cliff retreat rates on the south coast of Great Britain. Proc Natl Acad Sci USA 113:1333613341. https://doi.org/10.1073/pnas.1613044113

IGN (2020) Instituto Geográfico Nacional. Data available online at: http://pnoa.ign.es/presentacion-y-objetivo

James MR, Robson S, d'Oleire-Oltmanns S, Niethammer U (2017) Optimising UAV topographic surveys processed with structure-from-motion: ground control quality, quantity and bundle adjustment. Geomorphology 280:51-66. https://doi.org/10. 1016/j.geomorph.2016.11.021

Lee EM, Hall JW, Meadowcroft IC (2001) Coastal cliff recession: the use of probabilistic prediction methods. Geomorphology 40:253-269. https://doi.org/10.1016/S0169-555X(01)00053-8

Li X, Zhao C, Hölter R, Datcheva M, Alimardani Lavasan A (2019) Modeling of a large landslide problem under water level fluctuation-model calibration and verification. Geosciences 9:89. https://doi.org/10.3390/geosciences 9020089

Limber PW, Murray AB (2014) Unraveling the dynamics that scale cross-shore headland relief on rocky coastlines: 2 model predictions and initial tests. J Geophys Res Earth Surf 199:874-891. https://doi.org/10.1002/2013JF002950

Limber PW, Murray AB, Adams PN, Goldstein EB (2014) Unraveling the dynamics that scale cross-shore headland relief on rocky coastlines: 1 model development. J Geophys Res Earth Surf 120:854-873. https://doi.org/10.1002/2013JF002950

Limber PW, Barnard PL, Vitousek S, Erikson LH (2018) A model ensemble for projecting multidecadal coastal cliff retreat during the 21 st century. J Geophys Res Earth Surf 123(7):1566-1589. https://doi.org/10.1029/2017JF004401

Massey CI, Petley DN, McSaveney MJ (2013) Patterns of movement in reactivated landslides. Eng Geol 159:1-19. https://doi.org/10. 1016/j.enggeo.2013.03.011

McLean RF, Davidson CF (1968) The role of mass-movement in shore platform development along the Gisborne coastline, New Zealand. Earth Sci J 2:15-25

Medjkane M, Maquaire O, Costa S, Roulland T, Letortu P, Fauchard C, Antoine R, Davidson R (2018) High-resolution monitoring of complex coastal morphology changes: cross-efficiency of SfM and TLS-based survey (Vaches-Noires cliffs, Normandy, France). Landslides 15:1097-1108. https://doi.org/10.1007/ s10346-017-0942-4

Meteogalicia (2020) Data available online at: https://www.meteo galicia.gal/

Moore R, Davis G (2015) Cliff instability and erosion management in England and Wales. J Coast Conserv 19:771-784. https://doi. org/10.1007/s11852-014-0359-3

Muir-Wood AM (1971) Engineering aspects of coastal landslides. Proc Inst Civil Eng 50:257-276

Muñoz Narciso E, García H, Sierra Pernas C, Pérez-Alberti A (2017) Study of geomorphological changes by high quality DEMs, obtained from UAVs - structure from motion in highest continental cliffs of Europe: a Capelada (Galicia, Spain). Geophys Res Abstr EGU Gen Assem 19:2017-2692. https://doi.org/10. 13140/RG.2.2.24076.00647
Nandi A, Shakoor A (2010) A GIS-based landslide susceptibility evaluation using bivariate and multivariate statistical analyses. Eng Geol 110:11-20. https://doi.org/10.1016/j.enggeo.2009. 10.001

NASA (Goddard Space Flight Center) (2020) Satellite sea level observations. Online at: https://climate.nasa.gov/vital-signs/sea-level/

Polemio M, Petrucci O (2000) Rainfall as a landslide triggering factor: an overview of recent international research. In: Bromhead E, Dixon N, Ibsen M-L (eds) Landslides in research, theory and practice, proceedings of the 8th international symposium on landslides held in Cardiff, Wales on 26-30 June 2000. Thomas Telford, London, pp 1219-1226

Prémaillon M, Regard V, Dewez TJB, Auda Y (2018) GlobR2C2 (Global Recession Rates of Coastal Cliffs): a global relational database to investigate coastal rocky cliff erosion rate variations. Earth Surf Dynam 6:651-668. https://doi.org/10.5194/ esurf-6-651-2018

Puertos del Estado (2020) Data available online at: http://www.puert os.es/en-us/oceanografia/Pages/portus.aspx

Steger S, Brenning A, Bell R, Glade T (2017) The influence of systematically incomplete shallow landslide inventories on statistical susceptibility models and suggestions for improvements. Landslides 14:1767-1781. https://doi.org/10.1007/s10346-017-0820-0

Stephenson WJ, Dickson ME, Trenhaile AS (2021) Rock coasts. In: Shroder J, Sherman DJ (eds) Treatise on geomorphology, vol 10. Academic Press, San Diego, CA (Coastal geomorphology, Revised 2nd edition (2013 original))

Swirad ZM, Rosser NJ, Brain MJ, Rood DH, Hurst MD, Wilcken KM, Barlow J (2020) Cosmogenic exposure dating reveals limited long-term variability in erosion of a rocky coastline. Nat Commun 11:3804. https://doi.org/10.1038/s41467-020-17

Sytnik O, Del Río L, Greggio N, Bonetti J (2018) Historical shoreline trend analysis and drivers of coastal change along the Ravenna coast. NE Adriatic Environ Earth Sci 77:779. https://doi.org/10. 1007/s12665-018-7963-8

Trenhaile AS (1972) The shore platforms of the Vale of Glamorgan. Wales Trans Inst Brit Geogr 56:127-144

Trenhaile AS (1987) The geomorphology of rock coasts. Cavendish (Oxford) University Press, Oxford

Trenhaile AS (2002) Rock coasts, with particular emphasis on shore platforms. Geomorphology 48:7-22. https://doi.org/10.1016/ S0169-555X(02)00173-3

Trenhaile AS (2011) Predicting the response of hard and soft rock coasts to changes in sea level and wave height. Clim Change 109:599-615. https://doi.org/10.1007/s10584-011-0035-7

Trenhaile AS (2014a) Climate change and the impact on rocky coasts. In: Kennedy DA, Stephenson WJ, Naylor LA (eds) Rock coast geomorphology: a global synthesis. Memoir 40, Geological Society Books, London, pp 7-17

Trenhaile AS (2014b) Modelling tidal notch formation by wetting and drying and salt weathering. Geomorphology 224:139-151. https:// doi.org/10.1016/j.geomorph.2014.07.014

Trenhaile AS (2016) Rocky coasts-their role as depositional environments. Earth-Sci Rev 159:1-13. https://doi.org/10.1016/j.earsc irev.2016.05.001

Trenhaile AS (2019) Hard-rock coastal modelling: past practice and future prospects in a changing world. J Mar Sci Eng 7:1-16. https://doi.org/10.3390/jmse7020034

Trenhaile AS (2020) Modelling the development of dynamic equilibrium on shore platforms. Mar Geol 427:106227. https://doi.org/ 10.1016/j.margeo.2020.106227

USGS (2018) Digital Shoreline Analysis System (DSAS). Version 5.0. https://www.usgs.gov/centers/whcmsc/science/digital-shorelineanalysis-system-dsas?qt-science_center_objects=0\#qt-science_ center_objects. 
Valenzuela P, Domínguez-Cuesta MJ, Mora García MA, JiménezSánchez M (2018) Rainfall thresholds for the triggering of landslides considering previous soil moisture conditions (Asturias, NW Spain). Landslides 15:273-282. https://doi.org/10.1007/ s10346-017-0878-8

Vann Jones née Norman EC, Rosser NJ, Brain MJ, Petley DN (2015) Quantifying the environmental controls on erosion of a hard rock cliff. Mar Geol 363:230-242. https://doi.org/10.1016/j.margeo. 2014.12.008

Warrick JA, Ritchie AC, Schmidt KM, Reid E, Logan J (2019) Characterizing the catastrophic 2017 Mud Creek landslide, California, using repeat structure-from-motion (SfM) photogrammetry. Landslides 16:1201-1219. https://doi.org/10.1007/ s10346-019-01160-4

Westoby MJ, Lim M, Hogg M, Pound MJ, Dunlop L, Woodward J (2018) Cost-effective erosion monitoring of coastal cliffs. Coast
Eng 138:152-164. https://doi.org/10.1016/j.coastaleng.2018.04. 008

Wheaton JM, Brasington J, Darby SE, Sear DA (2010) Accounting for uncertainty in DEMs from repeat topographic surveys: improved sediment budgets. Earth Surf Process Landforms 35:136-156. https://doi.org/10.1002/esp.1886

Young AP (2018) Decadal-scale coastal cliff retreat in southern and central California. Geomorphology 300:164-175. https://doi.org/ 10.1016/j.geomorph.2017.10.010

Publisher's Note Springer Nature remains neutral with regard to jurisdictional claims in published maps and institutional affiliations. 